\title{
sciendo
}

\section{A new approach to cardiac fat volume assessment and the correlation with coronary artery calcification}

\author{
POOYA TORKIAN ${ }^{1 *}$, TARANEH FAGHIHI LANGROUDI ${ }^{1 *}$, AMIR MASOUD NEGARESTANI $^{1}$, ABBAS ARJMAND \\ SHABESTARI ${ }^{1}$, MOHAMMADREZA NADERIAN $^{2}$, MOHAMMADREZA TABARY $^{4}$, ISA KHAHESHI $^{3}$ \\ ${ }^{1}$ Radiology Department, Shahid Beheshti University of Medical Sciences, Tehran, Iran \\ ${ }^{2}$ Non-Communicable Diseases Research Center, Endocrinology and Metabolism Population Sciences Institute, \\ Tehran University of Medical Sciences, Tehran, Iran \\ ${ }^{3}$ Cardiovascular Research Center, Shahid Beheshti University of Medical Sciences, Tehran, Iran \\ ${ }^{4}$ School of medicine, Tehran University of Medical Sciences, Tehran, Iran \\ ${ }^{*}$ These two authors have contributed equally to this work.
}

Background. Coronary artery disease (CAD) is the foremost cause of death in the most developed societies. Plaque formation in epicardial coronary arteries and ensuing inflammation are a known pathophysiologic factor of CAD.

Objectives. We aimed to separately and simultaneously evaluate the correlation between pericardial fat pad volume and overall peri-coronary epicardial adipose tissue (EAT) thickness with coronary calcium score (CCS) to improve risk stratification of CAD.

Methods. We retrospectively reviewed patients who underwent a non-invasive contrastenhanced coronary multidetector CT (MDCT) angiography. Peri-coronary EAT thickness, pericardial fat pad volume and CCS were obtained by an expert radiologist from the patients coronary multidetector CT (MDCT) angiography.

Results. We included 141 symptomatic patients ( 86 men, 55 women) with an average age of $53.53 \pm 12.92$. An increment of overall peri-coronary EAT thickness $(1 / 3 \times($ left anterior descending artery (LAD) + left circumflex artery (LCx) + right coronary artery (RCA)) was associated with a $49 \%$ increase in the odds for the presence of coronary artery calcification (CAC) $(\mathrm{P}=0.004)$. Significant predictability of peri-coronary EAT-average was seen in diagnosing calcified plaque. Pericardial fat pad volume was positively correlated with overall peri-coronary EAT thickness in age and body mass index (BMI)-adjusted linear regression models, $(\mathrm{P}<0.001)$.

Conclusion. Our results amplify previous idea that peri-coronary EAT and pericardial fat pad volume might act as useful markers and better indicators of CCS based on Agatston score in comparison with BMI or body weight in order to reveal subsequent CADs.

Key words: multidetector computed tomography, coronary artery disease, adipose tissue, vascular calcification.

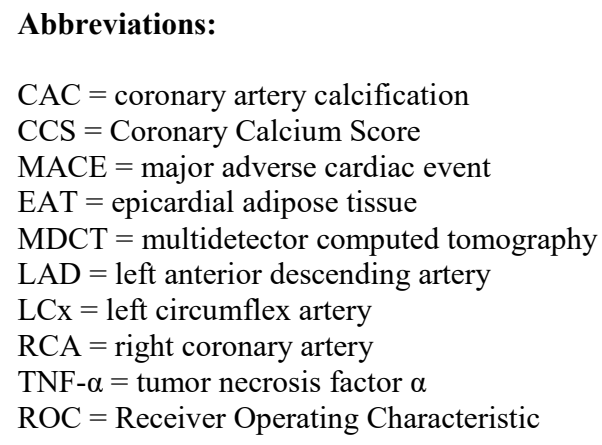

\section{INTRODUCTION}

By far, coronary artery disease (CAD) is the foremost cause of death in the most developed countries $[1,2]$. Plaque formation in epicardial coronary arteries and ensuing inflammation are a known pathophysiologic factor of CAD [3, 4]. Thereby, coronary artery stenosis can subsequently diminish the coronary artery blood flow and results in further devastating scenario such as myocardial infarction. Death rate has plummeted to less than a half by identifying and modifying various risk factors in advance [5, 6]. Clinical studies bear out the correlation between coronary artery calcification (CAC) as a pathognomonic evidence of coronary atherosclerosis quantified by Coronary Calcium 
Score (CCS) [7] and increased risk for subsequent major adverse cardiac event (MACE) [8]. Besides, excessive visceral fat as a criterion for metabolic syndrome has emerged as a contributing factor for a spectrum of CAD mainly by producing abundant bioactive molecules and inflammatory cytokines [9]. Right cardio-phrenic pericardial fat pad volume and peri-coronary epicardial adipose tissue (EAT) thickness were considered as indicators associated with CAD [10, 11]. While much of interest has been concentrated on the importance of echocardiography, there is limitation for precise measurement and reliable delineation of peri-coronary EAT thickness [12]. In this study we aim to separately and simultaneously evaluate the correlation between pericardial fat pad volume and peri-coronary EAT thickness with CCS to improve risk stratification of coronary artery events.

\section{MATERIALS AND METHODS}

\section{Study population}

We retrospectively collected the data of 141 all symptomatic patients who had underwent contrastenhanced multidetector computed tomography (MDCT) angiography for evaluation of the coronary arteries in Shahid Modarres hospital as a level-III cardiovascular disease referral center, affiliated to Shahid Beheshti University of Medical Sciences from August 30, 2015 to December 30, 2017. The protocol of the current study was approved by the local research ethics committees of the center. Subjects' baseline and clinical characteristics including age, gender, body mass index (BMI), history of smoking, presence of diabetes mellitus (DM), hypertension (HTN), hyperlipidemia (HLD), history of coronary artery bypass graft (CABG), and percutaneous coronary intervention (PCI) were determined based on their medical records archives. Patients with prior history of CABG, PCI, known allergies to iodinated contrast media, and renal failure (Glomerular filtration rate $<30 \mathrm{ml} / \mathrm{min}$ ) were excluded from our study.

\section{EAT measurement}

Images were reformatted to the usual planes used in cardiac imaging. EAT is defined as the epicardial adipose tissue within the pericardium surrounding the coronary arteries. Once a window level and window width are adjusted, the pericoronary EAT thickness surrounding the coronary arteries (LAD, RCA and LCx) were measured on axial plane, separately. In order not to overestimate peri-coronary EAT thickness; we selected the perpendicular section along each coronary artery to the heart surface (Figure 1). In cases of more than one section with this characteristic, the one with the most obvious EAT and maximal fat thickness was determined.

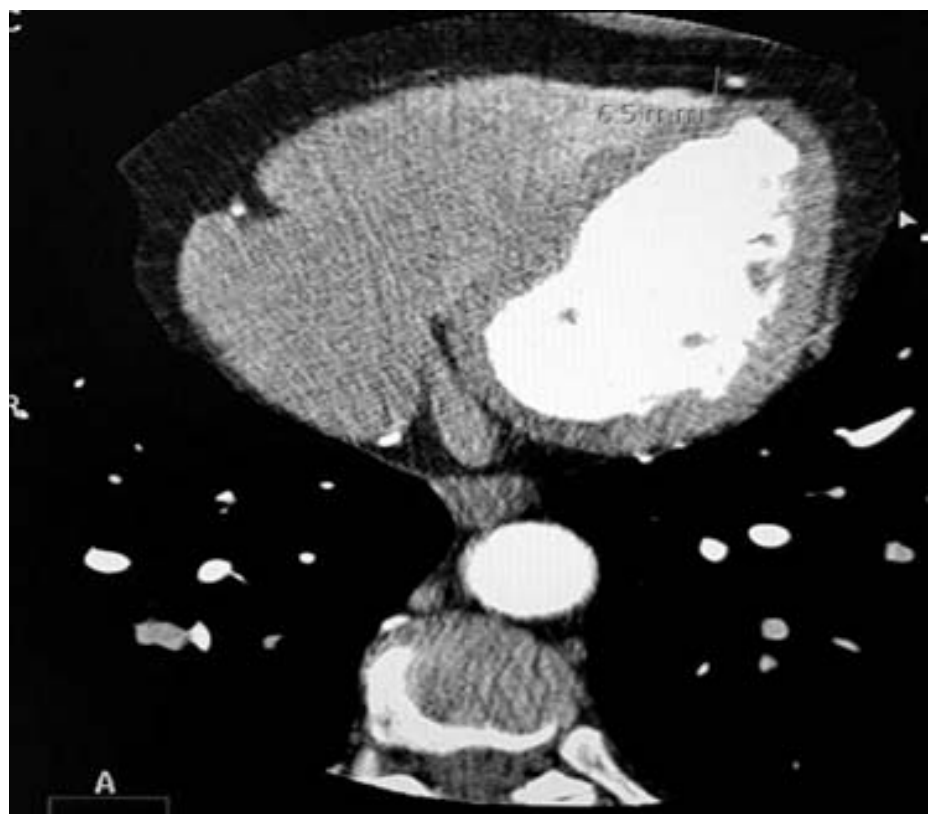

Figure 1. Coronary multidetector CT (MDCT) angiography in a 48-year old female presenting with acute chest pain with radiation to the left shoulder. Coronary CT angiography revealed pericardium, ventricular wall and peri-coronary epicardial adipose tissue (EAT) of LAD. Peri-coronary epicardial adipose tissue (EAT) measurement was done in the section perpendicular to the heart. MDCT: Multiple detector computed tomography, LAD: Left anterior descending artery. 


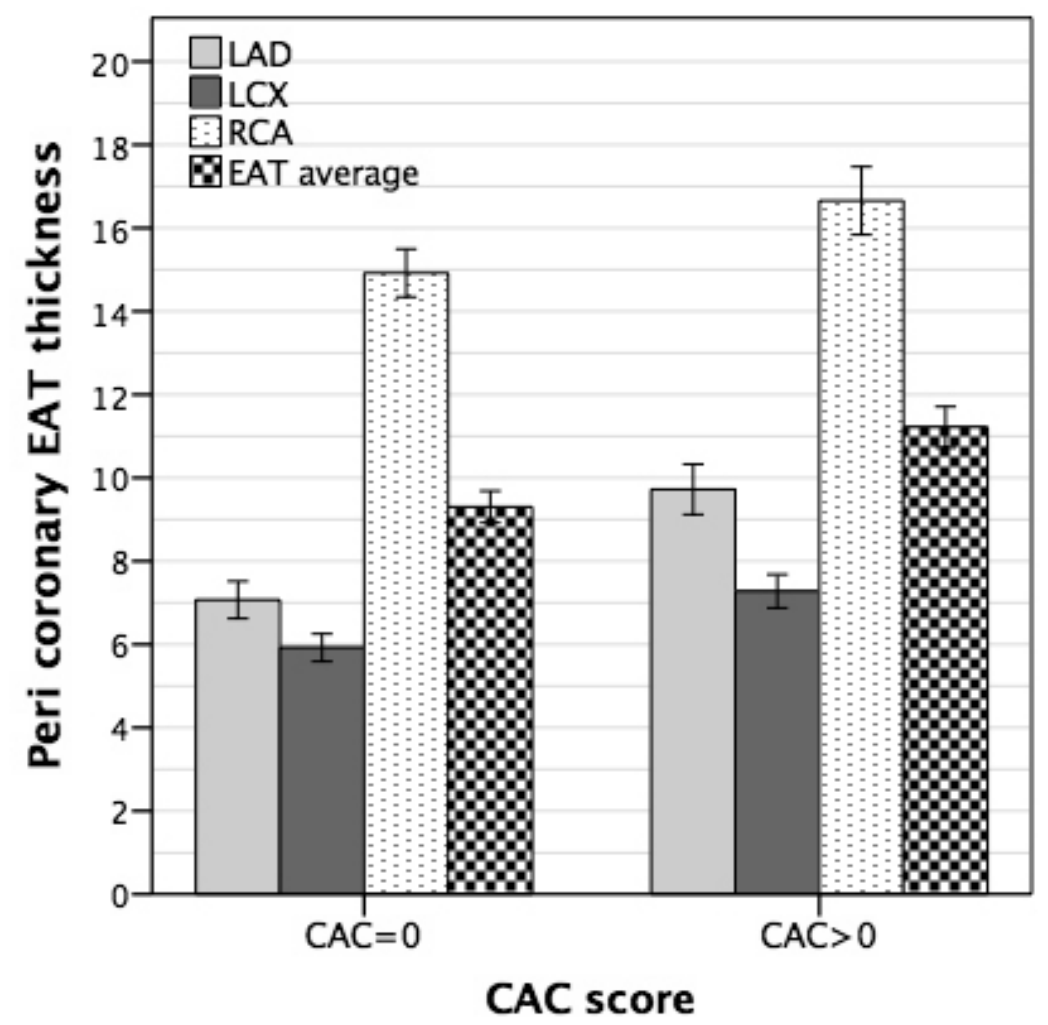

Supplementary Figure 1. Relation of calcium artery calcification (CAC) in different coronary arteries and peri-coronary EAT thickness.

\section{Pericardial fat pad volume measurement}

Due to lack of appropriate software, we developed a new protocol to measure the pericardial fat pad volume in the region of right cardio-phrenic angle on the existing cardiac CT scans. Measurement of pericardial fat pad volume was done practically by our protocol. Since the right cardio phrenic angle contains the thickest part of the adipose tissue, we measured pericardial fat pad volume in this region (Figure 2). To provide an accurate volumetric quantification of right cardio phrenic pericardial fat pad, we assumed a conical shape for the fat pad and we used the formula of cone volume for this measurement (volume of cone $=1 / 3 \times$ area of the base of cone $\times$ height of cone).

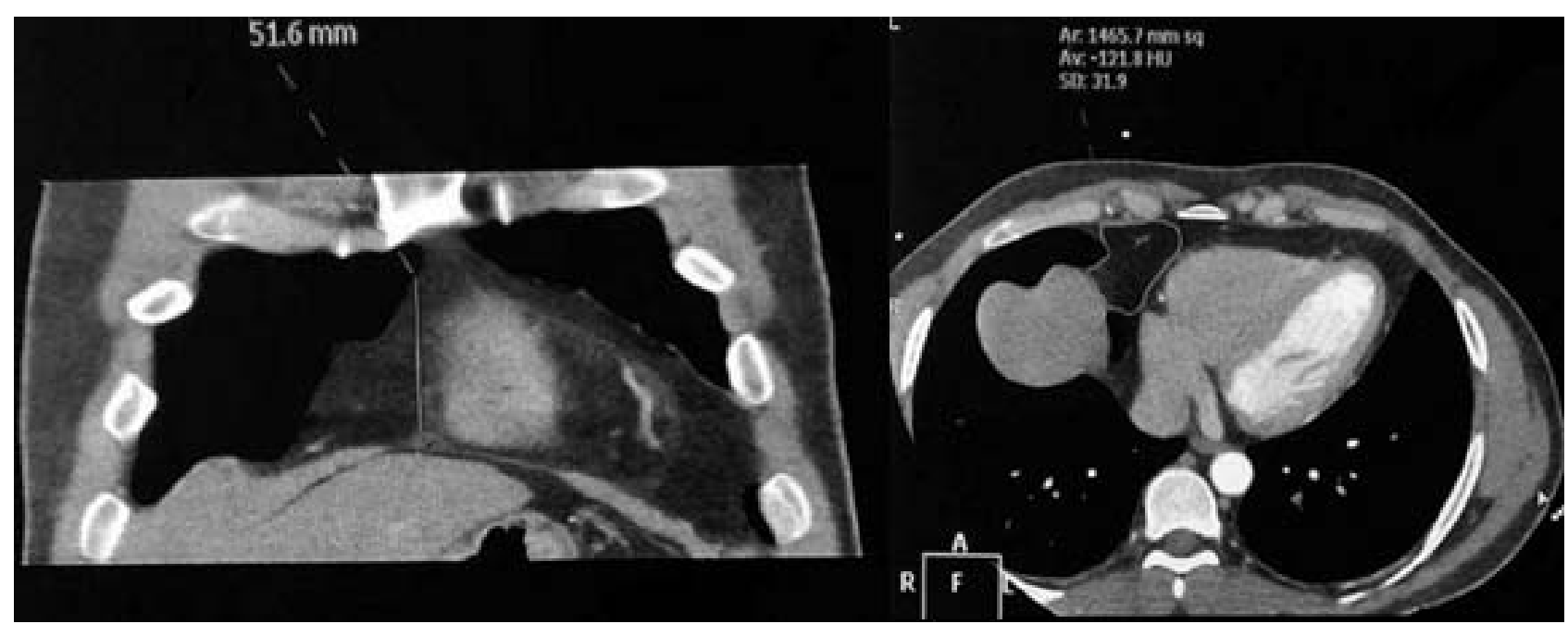

Figure 2. By considering conical shape of pericardial fat pat volume, we used the formula of cone volume for this measurement: a) Height measurement of right cardiophrenic pericardial fat pat in a 63-year old male as the height of cone.

b) Base of right cardiophrenic pericardial fat pat as the base of cone. 


\section{CAC scoring}

The usual coronary MDCT angiography protocol for patients with suspected CAD included $\mathrm{CAC}$ score measurement followed by noninvasive CT coronary angiogram. Initially, subjects underwent coronary calcium score measurement by a 64-row MDCT scanner (Brilliance 64, Philips Medical Systems, Cleveland, Ohio). Images are reconstructed with the following settings: collimation: $40 \times 0.625$ $\mathrm{mm}$; gantry rotation time: $0.4 \mathrm{~ms}$; tube voltage: $120 \mathrm{kV}$; and tube current: $45 \mathrm{mAs}$. During a single breath-hold, the scan started from the level of carina to the base of the heart. Prospective electrocardiography (ECG)-gated scan was performed depending on the heart rate, at $45 \%-60 \%$ of the ECG R-R interval. Each complete scan contained 50-60 contiguous, non-overlapping, $512 \times 512$ matrix slices over a 35 $\mathrm{cm}$ field of view with peak tube voltage of $120 \mathrm{kV}$ using $100 \mathrm{~ms}$ exposure time with $2.5 \mathrm{~mm}$ slices thickness. Images were evaluated by an expert cardiac radiologist blinded to the coronary angiographic results and EAT measurements. CAC score was measured as the mean Agatston score [13] by a semi-automated software (heartbeat-CS, Brilliance workspace, Philips medical system, Cleveland, $\mathrm{OH}$ ) using a detection of calcified plaque with threshold of 130 Hensfield unit
(HU) and minimum area of $1 \mathrm{~mm}^{2}$. The scores of individual lesions were added to obtain a global CAC Agatston score of all coronary vessels (left anterior descending artery (LAD), left circumflex artery (LCx), right coronary artery (RCA)) (Figure 3).

\section{Statistical analysis}

Mean \pm SD for continuous variables and frequency (percent) for categorical variables were reported as descriptive statistics. Linear regression models were used to determine the association of EAT (as a dependent variable) and measured variables adjusted for sex and age. After categorizing CAC into two levels of $\mathrm{CAC}=0$ and $\mathrm{CAC}>0$, the effects of EAT and PFV on calcification status $(\mathrm{CAC}>0)$ were evaluated using by binary logistic regression. Also, linear regression analysis was conducted for evaluating the association of PFV and CAS with EAT (as a dependent variable). Pearson and partial correlation tests were used to evaluate the relationships among EAT, CAC and PFV. Random sample was taken to repeat the measurement by the same and a second reader. The intra- and inter-rater reliability was 0.93 (95\% CI: $0.88-0.95)$ and 0.90 (95\% CI: 0.87-0.92) (Intraclass Correlation Coefficient).

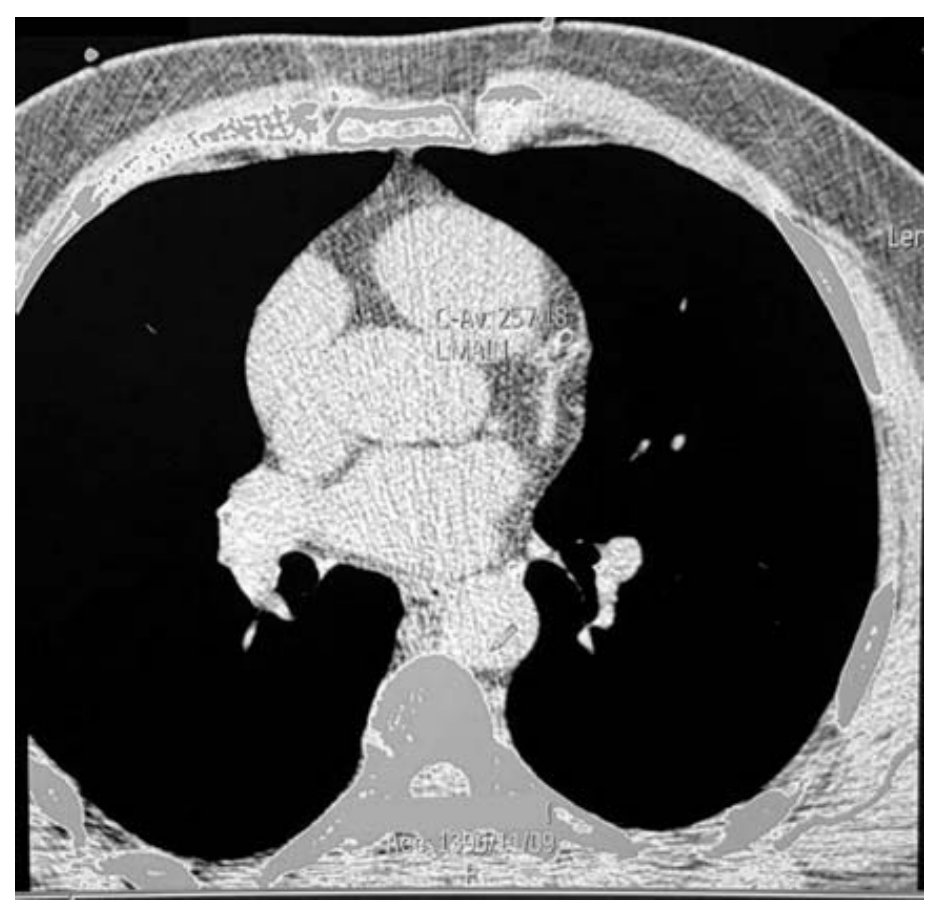

Figure 3. Coronary calcium scoring measurement based on agateston score in LAD coronary artery.

ROC (Receiver Operating Characteristic) curve analyses were performed to evaluate the EAT and PFV predictability to determine the patient's calcification status $(\mathrm{CAC}>0)$ and to assess the cut-off point values of EAT and PFV in predicting calcified patients. Sensitivity and specificity of EAT and PFV cut-off points for classifying subjects as CAC $>0$ were calculated in this analysis. 
All the statistical analyses were done by IBM SPSS Statistics 23 and $\mathrm{P}<0.05$ was considered as significant.

\section{RESULTS}

The clinical characteristics of the 141 patients (86 males, 55 females) with a mean age of $53.53 \pm$ 12.92 are summarized in Table 1 according to quartiles of overall peri-coronary EAT thickness (Complementary information in Supplementary Table 1). Mean BMI was $27.68 \pm 4.48 \mathrm{~kg} / \mathrm{m}^{2}$, and $29.8 \%$ of patients were obese $\left(>30 \mathrm{~kg} / \mathrm{m}^{2}\right)$. The average thickness of EAT around the RCA was $15.75 \pm 3.05 \mathrm{~mm}$ (ranging from 8.6 to $26.2 \mathrm{~mm}$ ) followed by $8.349 \pm 2.57 \mathrm{~mm}$ (ranging from $2.3 \mathrm{~mm}$ to $17.2 \mathrm{~mm}$ ) in the $\mathrm{LAD}$, and $6.57 \pm 1.68 \mathrm{~mm}$ in the LCx (ranging from $3.2 \mathrm{~mm}$ to $12 \mathrm{~mm}$ ). Highest EAT values (fourth quartile) was along with patients with an average elderly age, more likely men, higher BMI and higher abdominal fat (BMI $>30 \mathrm{~kg} / \mathrm{m}^{2}$ ) (P value $<0.05)$. Seventy-three patients had no coronary artery calcification based on CAC Agatston score of all coronary vessels (RCA $(\mathrm{n}=118), \mathrm{LAD}$ $(\mathrm{n}=77)$ and LCx $(\mathrm{n}=115))$ had zero CAC $)$. Evaluations of peri-coronary EAT thickness and the presences of coronary artery calcifications $(\mathrm{CAC}>0)$ were assessed using multivariable logistic regression analysis (Table 2) (Complementary information in Supplementary Table 2 to 5). An increment of overall peri-coronary EAT thickness was associated with a $49 \%$ increase in the odds for the presence of coronary artery calcification $(P=0.004)$. Furthermore, based on Table 2, an increment in the mean of pericardial fat pad volume was associated with $2 \%$ increase in the standardized beta coefficient $(P=0.044)$ for CAC $>0$. CCS levels were positively correlated with an overall peri-coronary EAT thickness $(\mathrm{P}=0.002)$. As shown in Table 3, partial correlation between coronary calcium scores and peri-coronary EAT thickness for LAD and RCA was direct and significant ( $\mathrm{P}=0.007,0.09$ respectively). In age and BMI adjusted linear regression models, pericardial fat pad volume was positively correlated with overall peri-coronary EAT thickness $(\mathrm{P}<0.001)$. In Table 4, when an adjustment was made for different variables, overall peri-coronary EAT thickness had a significant correlation with presence of coronary calcification. Based on Figure 4, the area under the ROC curve $(\mathrm{AUC}=0.80(95 \%$ CI: $0.72-0.87, \mathrm{P}<0.001))$ display the significant predictability of overall pericoronary EAT thickness in diagnosing patients with calcification (Complementary information in Supplementary Figure 1).

Table 1

Basic characteristics of study population among Epicardial Adipose Tissue quartiles

\begin{tabular}{|c|c|c|c|c|c|}
\hline \multirow[b]{2}{*}{ Variables } & \multicolumn{4}{|c|}{ Quartiles of EAT average } & \multirow[b]{2}{*}{ P-Value } \\
\hline & $\begin{array}{c}\text { Quartile 1 } \\
\leq 8.67\end{array}$ & $\begin{array}{c}\text { Quartile 2 } \\
8.68-9.80\end{array}$ & $\begin{array}{c}\text { Quartile 3 } \\
9.81-11.47\end{array}$ & $\begin{array}{c}\text { Quartile 4 } \\
>11.47\end{array}$ & \\
\hline EAT average & $7.90 \pm 0.64$ & $9.33 \pm 0.29$ & $10.56 \pm 0.46$ & $13.11 \pm 1.36$ & $<0.001$ \\
\hline Male gender & $21(60)$ & $18(51.4)$ & $26(72.2)$ & $21(60)$ & 0.35 \\
\hline Age (year) & $43.34 \pm 11.41$ & $52.54 \pm 11.16$ & $55.19 \pm 11.33$ & $63.00 \pm 9.89$ & $<0.001$ \\
\hline Weight (kg) & $76.59 \pm 10.46$ & $76.69 \pm 12.73$ & $80.78 \pm 9.71$ & $78.94 \pm 10.44$ & 0.33 \\
\hline Height $(\mathrm{cm})$ & $172.3 \pm 11.59$ & $166.4 \pm 8.65$ & $172.1 \pm 11.29$ & $164.1 \pm 8.47$ & 0.03 \\
\hline BMI $\left(\mathrm{kg} / \mathrm{m}^{2}\right)$ & $26.00 \pm 4.07$ & $27.64 \pm 3.80$ & $27.51 \pm 4.37$ & $29.57 \pm 5.03$ & 0.02 \\
\hline Smoking & $2(5.7)$ & $3(8.6)$ & $8(22.2)$ & $6(17.1)$ & 0.08 \\
\hline DM & $4(11.4)$ & $1(2.9)$ & $4(11.1)$ & $6(17.1)$ & 0.91 \\
\hline HTN & $5(14.3)$ & $9(25.7)$ & $10(27.8)$ & $22(62.9)$ & 0.42 \\
\hline HLD & $10(28.6)$ & $6(17.1)$ & $10(28.6)$ & $16(45.7)$ & 0.93 \\
\hline Obesity (BMI > 30) & $6(17.1)$ & $10(28.6)$ & $10(28.6)$ & $16(45.7)$ & 0.04 \\
\hline Pericardial Fat Pad Volume $\left(\mathrm{cm}^{3}\right)$ & $15.12(1-80.8)$ & $20.40(3.6-58.2)$ & $32.98(1.8-127)$ & $36.61(1-233)$ & $<0.001$ \\
\hline LAD calcium & $0(0-156)$ & $0(0-97)$ & $1.4(0-104)$ & $78(0-711)$ & $<0.001$ \\
\hline LCx calcium & $0(0-50)$ & $0(0-28)$ & $0(0-268)$ & $0(0-461)$ & 0.15 \\
\hline RCA calcium & $0(0-230)$ & $0(0-24)$ & $0(0-183)$ & $0(0-230)$ & 0.33 \\
\hline CAC score & $0(0-436)$ & $0(0-110)$ & $1.9(0-319)$ & $105(0-942)$ & $<0.001$ \\
\hline $\mathrm{CAC}>0$ & $5(14.3)$ & $11(31.4)$ & $23(63.9)$ & $29(83.9)$ & 0.003 \\
\hline
\end{tabular}

Variables are presented as $\mathrm{n}(\%)$, mean + SD or median (min-max). The last column shows significance in the age and gender adjusted linear regression analysis, with average EAT thickness of the three coronary arteries as dependent variable. The cut points of the quartiles are $8.67,9.80$ and $11.47 \mathrm{~mm}$.

BMI: body mass index, DM: diabetes mellitus, HTN: hypertension, HLD: hyperlipidemia, PFV: pericardial fat pad volume, EAT: epicardial adipose tissue, CAC: coronary artery calcification, LAD: left anterior descending artery, LCx: left circumflex artery, RCA: right coronary artery. 


\section{Supplementary Table 1}

Basic characteristics of study population

\begin{tabular}{ll}
\hline \multicolumn{1}{c}{ Variables } & \multicolumn{1}{c}{ Statistics } \\
\hline Male gender & $86(61 \%)$ \\
Age (year) & $53.53 \pm 12.92(24-79)$ \\
Weight $(\mathrm{kg})$ & $78.28 \pm 10.91(50-110)$ \\
Height $(\mathrm{cm})$ & $168.7 \pm 10.62(145-198)$ \\
BMI $\left(\mathrm{kg} / \mathrm{m}^{2}\right)$ & $27.68 \pm 4.48(18.3-39.2)$ \\
Smoking & $19(13.5 \%)$ \\
DM & $15(10.6 \%)$ \\
HTN & $46(32.6 \%)$ \\
HLD & $42(29.8 \%)$ \\
Obesity $($ BMI $>30)$ & $42(29.8 \%)$ \\
Pericardial Fat Pad Volume $\left(\mathrm{cm}^{3}\right)$ & $31.15 \pm 28.6(2.3-17.2)$ \\
LAD adipose tissue & $8.35 \pm 2.58(3.2-12.0)$ \\
LCX adipose tissue & $6.58 \pm 1.68(8.6-26.2)$ \\
RAD adipose tissue & $15.76 \pm 3.06(5.3-16.1)$ \\
EAT average & $10.23 \pm 2.07(1-233)$ \\
LAD calcium & $41.71 \pm 104.1(0-711)$ \\
LCx calcium & $10.43 \pm 47.2(0-461)$ \\
RAD calcium & $12.37 \pm 44.0(0-230)$ \\
CAC score & $64.52 \pm 159.8(0-942)$ \\
\hline
\end{tabular}

Data are shown as mean \pm SD (min - max) for continuous and $n(\%)$ for categorical variables. BMI: body mass index, DM: diabetes mellitus, HTN: hypertension, HLD: hyperlipidemia, PFV: pericardial fat pad volume, EAT: epicardial adipose tissue, CAC: coronary artery calcification, LAD: left anterior descending artery, LCx: left circumflex artery, RCA: right coronary artery.

Table 2

Association of pericardial fat pad volume with coronary artery calcification (Odds ratio and $95 \%$ confidence interval for $\mathrm{CAC}>0$ affected by pericardial fat pad volume and risk factors)

\begin{tabular}{|c|c|c|c|c|c|c|}
\hline \multirow{2}{*}{ Variables } & \multicolumn{3}{|c|}{ Simple analysis } & \multicolumn{3}{|c|}{ Multiple analysis ${ }^{*}$} \\
\hline & $\beta$ & $95 \%$ CI & P-Value & $\boldsymbol{\beta}$ & $95 \% \mathrm{CI}$ & P-Value \\
\hline Male gender & 3.26 & $1.59-6.67$ & 0.001 & 6.46 & $2.31-18.1$ & $<0.001$ \\
\hline Age (year) & 1.13 & $1.09-1.18$ & $<0.001$ & 1.16 & $1.10-1.22$ & $<0.001$ \\
\hline BMI $\left(\mathrm{kg} / \mathrm{m}^{2}\right)$ & 1.09 & $1.01-1.18$ & 0.026 & & & \\
\hline Smoking & 3.53 & $1.20-10.4$ & 0.001 & 4.36 & $0.90-21.1$ & 0.067 \\
\hline DM & 3.33 & $1.01-11.0$ & 0.049 & & & \\
\hline HTN & 4.35 & $2.02-9.35$ & $<0.001$ & & & \\
\hline HLD & 2.95 & $1.38-6.29$ & 0.005 & & & \\
\hline PFV & 1.03 & $1.01-1.04$ & 0.002 & 1.02 & $1.01-1.04$ & 0.044 \\
\hline
\end{tabular}

* Backward stepwise analysis was used to determine the significant ORs. BMI: body mass index, DM: diabetes mellitus, HTN: hypertension, HLD: hyperlipidemia, PFV: pericardial fat pad volume, EAT: epicardial adipose tissue, CAC: coronary artery calcification, LAD: left anterior descending artery, LCx: left circumflex artery, RCA: right coronary artery.

\section{Supplementary Table 2}

Association of peri-coronary EAT with coronary artery calcification (Odds ratio and $95 \%$ confidence interval for $\mathrm{CAC}>0$ effected by EAT and risk factors)

\begin{tabular}{|c|c|c|c|c|c|c|}
\hline \multirow{2}{*}{ Variables } & \multicolumn{3}{|c|}{ Simple analysis } & \multicolumn{3}{|c|}{ Multiple analysis of EAT * } \\
\hline & OR & $95 \% \mathrm{CI}$ & P-Value & OR & $95 \%$ CI & P-Value \\
\hline Male gender & 3.26 & $1.59-6.67$ & 0.001 & 8.82 & $3.07-25.3$ & $<0.001$ \\
\hline Age (year) & 1.13 & $1.09-1.18$ & $<0.001$ & 1.13 & $1.08-1.19$ & $<0.001$ \\
\hline BMI $\left(\mathrm{kg} / \mathrm{m}^{2}\right)$ & 1.09 & $1.01-1.18$ & 0.026 & & & \\
\hline Smoking & 3.53 & $1.20-10.4$ & 0.001 & & & \\
\hline DM & 3.33 & $1.01-11.0$ & 0.049 & & & \\
\hline HTN & 4.35 & $2.02-9.35$ & $<0.001$ & & & \\
\hline HLD & 2.95 & $1.38-6.29$ & 0.005 & & & \\
\hline EAT average & 1.80 & $1.43-2.87$ & $<0.001$ & 1.49 & $1.13-1.95$ & 0.004 \\
\hline LAD EAT & 1.77 & $1.44-2.18$ & $<0.001$ & & & \\
\hline LCx EAT & 1.79 & $1.38-2.31$ & $<0.001$ & & & \\
\hline RCA EAT & 1.23 & $1.08-1.39$ & 0.001 & & & \\
\hline
\end{tabular}

Pericardial adipose tissue of LAD, LCX and RAD were not entered in multiple analysis. " Backward stepwise analysis was used to determine the significant ORs. BMI: body mass index, DM: diabetes mellitus, HTN: hypertension, HLD: hyperlipidemia, PFV: pericardial fat pad volume, EAT: epicardial adipose tissue, CAC: coronary artery calcification, LAD: left anterior descending artery, LCx: left circumflex artery, RCA: right coronary artery. 
Table 3

Correlation of coronary calcium score and peri-coronary EAT thickness

\begin{tabular}{|l|c|c|c|c|}
\hline \multirow{2}{*}{ Variables } & LAD EAT & LCX EAT & RCA EAT & EAT average \\
\cline { 2 - 5 } & correlation (P-value) & correlation (P-value) & correlation (P-value) & correlation (P-value) \\
\hline LAD calcium & $0.23(0.007)$ & $0.25(0.003)$ & $0.24(0.004)$ & $0.30(<0.001)$ \\
\hline LCx calcium & $0.14(0.10)$ & $0.11(0.22)$ & $0.07(0.40)$ & $0.13(0.14)$ \\
\hline RCA calcium & $0.02(0.79)$ & $0.03(0.74)$ & $0.14(0.09)$ & $0.08(0.36)$ \\
\hline CAC score & $0.21(0.017)$ & $0.19(0.027)$ & $0.23(0.008)$ & $0.26(0.002)$ \\
\hline
\end{tabular}

Age and BMI are controlling variables. BMI: body mass index, DM: diabetes mellitus, HTN: hypertension, HLD: hyperlipidemia, PFV: pericardial fat pad volume, EAT: epicardial adipose tissue, CAC: coronary artery calcification, LAD: left anterior descending artery, LCx: left circumflex artery, RCA: right coronary artery, CCS: coronary calcium score.

\section{Supplementary Table 3}

Simple and multiple linear regression analysis for evaluating the association of pericardial fat pad volume and coronary artery calcification with peri-coronary EAT thickness

\begin{tabular}{|l|c|c|c|c|c|c|}
\hline \multirow{2}{*}{\multicolumn{1}{c|}{ Variables }} & \multicolumn{3}{|c|}{ Simple analysis } & \multicolumn{3}{c|}{ Multiple analysis* } \\
\cline { 2 - 7 } & $\boldsymbol{\beta}$ & $\mathbf{9 5 \%}$ CI & P-Value & $\boldsymbol{\beta}$ & $\mathbf{9 5 \%}$ CI & P-Value \\
\hline Male gender & -0.07 & $-0.78-0.63$ & 0.84 & & & $<0.001$ \\
\hline Age (year) & 0.08 & $0.06-0.11$ & $<0.001$ & 0.06 & $0.03-0.08$ & 0.040 \\
\hline BMI $\left(\mathrm{kg} / \mathrm{m}^{2}\right)$ & 0.13 & $0.06-0.21$ & 0.001 & 0.07 & $0.01-0.13$ & \\
\hline Smoking & 0.99 & $0.01-1.98$ & 0.048 & & & \\
\hline DM & 0.59 & $-0.53-1.70$ & 0.30 & & & \\
\hline HTN & 1.31 & $0.61-2.02$ & $<0.001$ & & & \\
\hline HLD & -0.61 & $-0.14-1.36$ & 0.11 & & & \\
\hline CAC $>0$ & 1.92 & $1.30-2.53$ & $<0.001$ & 0.73 & $0.04-1.42$ & 0.038 \\
\hline PFV & 0.03 & $0.02-0.04$ & $<0.001$ & 0.02 & $0.01-0.03$ & 0.001 \\
\hline
\end{tabular}

"Backward stepwise analysis was used to determine the significant variables. EAT was considered continuous dependent variable. BMI: body mass index, DM: diabetes mellitus, HTN: hypertension, HLD: hyperlipidemia, PFV: pericardial fat pad volume, EAT: epicardial adipose tissue, CAC: coronary artery calcification, LAD: left anterior descending artery, LCx: left circumflex artery, RCA: right coronary artery.

Table 4

Association of pericardial fat pad volume and EAT with coronary calcification (OR and $95 \%$ confidence interval for CAC $>0$ affected by pericardial fat pad volume and EAT-average simultaneously)

\begin{tabular}{|l|c|c|c|c|c|c|c|c|c|}
\hline \multirow{3}{*}{ Variables } & \multicolumn{3}{|c|}{ Model 1 } & \multicolumn{3}{c|}{ Model 2 } & \multicolumn{3}{c|}{ Model 3 } \\
\cline { 2 - 10 } & OR & $\mathbf{9 5 \%}$ CI & P-Value & OR & $\mathbf{9 5 \% ~ C I ~}$ & P-Value & OR & 95\% CI & P-Value \\
\hline PFV & 1.01 & $0.99-1.03$ & 0.149 & 1.01 & $0.99-1.03$ & 0.291 & 1.01 & $0.99-1.03$ & 0.271 \\
\hline EAT-average & 1.71 & $1.34-2.18$ & $<0.001$ & 1.41 & $1.10-1.87$ & 0.016 & 1.41 & $1.04-1.90$ & 0.026 \\
\hline
\end{tabular}

Model 1: the variables of pericardial fat pad volume and EAT-average entered into model.

Model 2: effect of pericardial fat pad volume and Eat-average adjusted with age, gender and BMI.

Model 3: effect of pericardial fat pad volume and Eat-average adjusted with age, gender, BMI, smoking, DM, HTN. BMI: body mass index, DM: diabetes mellitus, HTN: hypertension, HLD: hyperlipidemia, PFV: pericardial fat pad volume, EAT: epicardial adipose tissue, CAC: coronary artery calcification, LAD: left anterior descending artery, LCx: left circumflex artery, RCA: right coronary artery, CCS: coronary calcium score.

\section{Supplementary Table 4}

Correlation of coronary calcium score and peri-coronary EAT thickness.

\begin{tabular}{|l|c|c|c|c|}
\hline \multirow{2}{*}{ Variables } & LAD EAT & LCX EAT & RCA EAT & EAT average \\
\cline { 2 - 5 } & correlation (P-value) & correlation (P-value) & correlation (P-value) & correlation (P-value) \\
\hline LAD calcium & $0.23(0.007)$ & $0.25(0.003)$ & $0.24(0.004)$ & $0.30(<0.001)$ \\
\hline LCx calcium & $0.14(0.10)$ & $0.11(0.22)$ & $0.07(0.40)$ & $0.13(0.14)$ \\
\hline RCA calcium & $0.02(0.79)$ & $0.03(0.74)$ & $0.14(0.09)$ & $0.08(0.36)$ \\
\hline CAC score & $0.21(0.017)$ & $0.19(0.027)$ & $0.23(0.008)$ & $0.26(0.002)$ \\
\hline
\end{tabular}

Age and BMI are controlling variables. BMI: body mass index, DM: diabetes mellitus, HTN: hypertension, HLD: hyperlipidemia, PFV: pericardial fat pad volume, EAT: epicardial adipose tissue, CAC: coronary artery calcification, LAD: left anterior descending artery, LCx: left circumflex artery, RCA: right coronary artery, CCS: coronary calcium score. 
Supplementary Table 5

Correlation of coronary calcium score and peri coronary EAT thickness with pericardial fat pad volume

\begin{tabular}{|l|c|c|c|c|}
\hline \multicolumn{1}{|c|}{ Variables } & Correlation & P-value & Correlation $^{*}$ & P-value $^{* \mid}$ \\
\hline LAD calcium & 0.18 & 0.034 & 0.12 & 0.18 \\
\hline LCx calcium & 0.05 & 0.55 & 0.012 & 0.89 \\
\hline RCA calcium & 0.07 & 0.41 & 0.012 & 0.89 \\
\hline CAC score & 0.15 & 0.08 & 0.08 & 0.33 \\
\hline LAD EAT & 0.37 & $<0.001$ & 0.33 & $<0.001$ \\
\hline LCX EAT & 0.38 & $<0.001$ & 0.34 & $<0.001$ \\
\hline RAD EAT & 0.20 & 0.02 & 0.13 & $<0.12$ \\
\hline EAT average & 0.35 & $<0.001$ & 0.30 & $<01$ \\
\hline
\end{tabular}

Adjusted for age and BMI.

BMI: body mass index, DM: diabetes mellitus, HTN: hypertension, HLD: hyperlipidemia, PFV: pericardial fat pad volume, EAT: epicardial adipose tissue, CAC: coronary artery calcification, LAD: left anterior descending artery, LCx: left circumflex artery, RCA: right coronary artery, CCS: coronary calcium score.
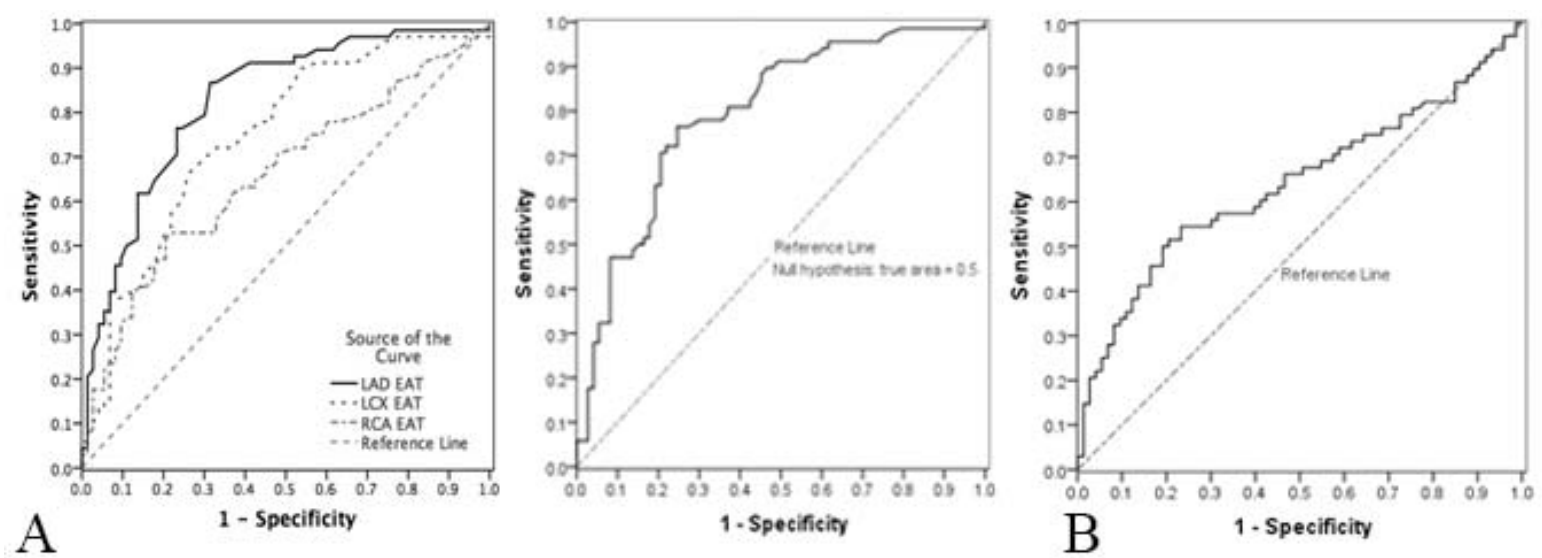

Figure 4. The ROC analysis for evaluating the EAT-average and pericardial fat pad volume cut-off point. A) The ROC analysis for evaluating the EAT-average cut-off point to predict the calcification status (CAC $>0$ ), Area under curve was equal to 0.80 (95\% CI: 0.72-0.87). The ROC analysis for evaluating the cut-off point of three coronary EATs (LAD, LCx and RAD) to predict the calcification status $(\mathrm{CAC}>0)$. The area under curve equal to $0.83(95 \% \mathrm{CI}: 0.76-0.90, \mathrm{P}<0.001)$ for LAD-EAT, 0.75 (95\% CI: 0.68-0.83, P < 0.001) for LCX-EAT and the area for RCA-EAT equal to 0.66 (95\% CI: $0.57-0.75, \mathrm{P}=0.001)$. There was significant predictability of all three peri-coronary EATs in recognizing calcified plaques. B) The ROC analysis for evaluating the pericardial fat pad volume, cut-off point to predict the calcification status $(\mathrm{CAC}>0)$, Area under curve was equal to $0.64(95 \% \mathrm{CI}: 0.55-0.73)$. In the evaluation of pericardial fat pad volume predictability to determine the patient's calcification status $(\mathrm{CAC}>0)$ and assessing the cut-off value for pericardial fat pad volume in predicting calcified patients using ROC analyses (Figure 1), the area under curve was equal to 0.64 (95\% CI: $0.55-0.73, \mathrm{P}=0.004)$ displaying the significant predictability of pericardial fat pad volume in recognizing of calcified plaques. The cut-off point, sensitivity, and specificity of pericardial fat pad volume, to classify subjects as CAC $>0$ were $13.5,61 \%$, and $60 \%$, respectively pericardial fat pad volume: pericardial fat pad volume, EAT: epicardial adipose tissue, CAC: coronary artery calcification

\section{DISCUSSION}

This study reveals two main original findings, which previous studies didn't discuss. Formerly a correlation between overall peri-coronary EAT thickness and pericardial fat pad volume with CAC was seen $[14,15]$. Primarily, we aimed to study effects of both these factors separately and simultaneously and assess their impacts on CCS based on Agatston score in Iranian patients. Secondly, we determine the most effective predictor factor that diagnostician can rely upon to improve risk stratification of subsequent coronary artery events. Although some authors have suggested abdominal obesity (BMI, waist circumference) as the main determinant of CVD [16], some epidemiological studies were opposed to that finding, reflecting that calculating body weight can't impeccably reflect further CAD events [17]. Excess amount of fat depot in upper body regardless of whether the body weight is above normal range or is not correlated with higher CAD events.

There were studies indicating a welldocumented role of pericardial fat pad volume and peri-coronary EAT thickness quantified from cardiac $\mathrm{CT}$ in both obese and non-obese community with acceleration of coronary atherosclerosis [18]. Those studies opine that fat accumulation in special regions 
can be a better indicator of calcified plaques in vessels based on Agatston scores which can aware us of the subsequent CAD events. This causal relationship is substantiated by the existence of visceral fat in the adjacent arterial wall and its exertion by releasing inflammatory cytokines [19]. A study by Ding et al. has shown the association between pericardial fat pad volume and CAD [20]. Although presence of fat depot in pericardial region has been considered as an aging process, it may play a role in the development of CAD [21]. Obese patients are more prone to experience atherogenesis as a result of higher levels of inflammatory cytokine cascade leading to accelerating atherogenesis. Inflammatory mediators released from pericardial fat may lead to coronary atherosclerosis by contributing towards vascular smooth muscle cell proliferation in coronary arteries [19]. In the previous studies, when an adjustment was made for the most cardiovascular traditional risk factors, an increment of pericardial fat pad volume was a correlate of increased CAD incidences in communitybased individuals with no history of CVDs [22]. Aforementioned results owing to the proximity of fat depot around the heart to the coronary arteries and calcified coronary plaque induced by influx of inflammatory cells. Numerous cytokines such as interleukin 1 (IL-1 $\beta$ ), interleukin 6 (IL-6) and tumor necrosis factor $\alpha(\mathrm{TNF}-\alpha)$ were pronounced in adipose tissue, which can amplify this phenomenon.

Numerous studies have led to the endocrine characteristics of peri-coronary EAT thickness and its impact via bioactive metabolites near the coronary vessel $[1,10,12]$. Besides, a low level of a known anti-inflammatory protein called adiponectin, which is secreted by adipose tissue locally, can have a crucial role in the pathogenesis of CAD [14]. On the contrary, some studies postulated that peri-coronary EAT thickness are not associated with the extent of CCS due to their different understudied population. In the present study, ROC analysis indicated that peri-coronary EAT thickness and pericardial fat pad volume could be clinically useful for determining the presence of CAC detected by coronary MDCT angiography.

Our results amplify previous idea that pericoronary EAT and pericardial fat pad volume might act as useful markers and better indicators of CCS based on Agatston score in comparison with BMI or body weight in order to revealing subsequent CADs. Although we had 73 patients with zero CCS in our study, zero level of CCS doesn't indicate low prevalence of subsequent $\mathrm{CAD}$ in symptomatic patients or patients who were at high risk for cardiovascular events. CAD can occur because of non-calcified plaque as a result of different scenarios and broad individual variation, which necessitates further invasive diagnostic intervention.

Although presences of CAC increased with an increment in quartiles of the three-peri coronary EAT thicknesses, there was regional variation in their associations. The peri coronary EAT thickness and right cardiophrenic pericardial fat pad volume can be measured in non-contrast thin section spiral CT scan. Hence, by evaluating the correlation between these two variables and the coronary calcium score, we will be able to guess the possibility of presence or future likelihood of atherosclerotic changes in patient's coronary arteries based on non-contrast thin section spiral CT scan of chest, which is performed for other reasons.

Another aspect of measuring epicardial fat pad is beyond the prediction of coronary calcification. A study by Nappi et al. showed that there was a correlation between EAT volume and myocardial perfusion reserve in patients with CAC score $=0$ $(\mathrm{P}=0.014)$, while this correlation was not significant in patients with CAC score $>0$. This fact implicates the superiority of EAT volume measurements to CAC score in patients with abnormal myocardial perfusion [23]. Present works are using machine learning including EAT volume to predict cardiovascular event. It has been shown that this machine learning models works better than EAT or CAC score itself; however, due to limited resources in developing countries, simple predictors such as EAT volume are more practical [24]. Aslanabadi et al. have performed a similar study on 150 patients and assessed epicardial and pericardial fat pad volume [25]. There are some differences between the study by Aslanabadi et al. and ours: We measured epicardial fat pat in different coronary vessels and this aspect is novel. Further, our analysis included adjustment for confounders, while Aslanabadi et al. did not adjust their measurement for confounding factors. There were some limitations in this study. Firstly, the current study was of a cross-sectional nature. No definitive cause-effect relation could be drawn. Secondly, only patients with suspected CAD referred for MDCT were included in the study; therefore, this sample may not extrapolate the general population. Thirdly, we developed a new protocol to measure the pericardial fat pad volume in the region of right cardio-phrenic on the existing cardiac CT scans so there are possibilities of inter 
observer and intra observer variability. Hence, future studies in larger multicenter studies with long-term follow-up and accurate software-based measurements with MSCT should be performed to precisely assess these findings.

\section{CONCLUSION}

Increase quartiles of overall pericoronary EAT thickness and pericardial fat pad volume had a significant correlation with $\mathrm{CAC}>0$.

Introducere. Boala coronariană (CAD) este o cauză principală a mortalității in țările dezvoltate. Formarea plăcii în arterele coronariene epicardice alături de inflamație sunt cauze cunoscute.

Obiectiv. Obiectivul studiului a fost evaluarea separată şi simultană a corelației dintre volumul grăsimii pericardice şi grosimea totală a țesutului adipos epicardic pericoronarian (EAT) cu scorul calcic coronarian (CCS) în vederea îmbunătățirii stratificării riscului de boală coronariană.

Metode. Au fost evaluați retrospectiv pacienții ce au fost supuşi unei angiografii coronariană tip multidetector CT (MDCT). Grosimea pericoronară a EAT, volumul gras pericardic şi CCS au fost determinate de către experți radiologi din analiza MDCT.

Rezultate. Au fost incluşi 141 pacienți simptomatici (86 bărbați şi 55 femei) cu o vârtsă medie de 53,53 $\pm 12,92$. O creştere a grosimii totale a grăsimii EAT s-a asociat cu creşterea a riscului cu $49 \%$ a prezenței calcificărilor coronare (CAC, $p=0,004)$. Grăsimea pericardică s-a corelat cu grosimea totală a EAT după ajustarea pentru vârstă şi BMI.

Concluzii: Rezultatele obținute întăresc ipoteza că EAT pericoronarian şi volumul de grăsime pericardică pot fi predictor buni pentru CCS bazat pe scorul Agatson comparativ cu BMI sau greutatea pentru a decela CAD.

Correspondence to: Isa Khaheshi, MD Cardiovascular Research Center, Shahid Beheshti University of Medical Sciences, Tehran, Iran, postal code: 1983969411

E-mail: isa.khaheshi@gmail.com

Conflict of interest disclosure: The authors declare no conflict of interest.

Acknowledgments: None declared.

\section{REFERENCES}

1. HANSSON G.K., Inflammation, atherosclerosis, and coronary artery disease, N. Engl. J. Med., 2005, 352(16):1685-95.

2. SUWAIDI J.A., HAMASAKI S., HIGANO S.T., NISHIMURA R.A., HOLMES D.R. Jr., LERMAN A., Long-term follow-up of patients with mild coronary artery disease and endothelial dysfunction, Circulation, 2000, 101(9):948-54.

3. FUSTER V., BADIMON L., BADIMON J.J., CHESEBRO J.H., The pathogenesis of coronary artery disease and the acute coronary syndromes (2), N. Engl. J. Med., 1992, 326(5):310-8.

4. LIBBY P., THEROUX P., Pathophysiology of coronary artery disease, Circulation, 2005, 111(25):3481-8.

5. LIAO J., FARMER J., Arterial stiffness as a risk factor for coronary artery disease, Curr. Atheroscler. Rep., 2014, $16(2): 387$.

6. MCCLELLAND R.L., JORGENSEN N.W., BUDOFF M., BLAHA M.J., POST W.S., KRONMAL R.A. et al., 10-Year Coronary Heart Disease Risk Prediction Using Coronary Artery Calcium and Traditional Risk Factors: Derivation in the MESA (Multi-Ethnic Study of Atherosclerosis) with Validation in the HNR (Heinz Nixdorf Recall) Study and the DHS (Dallas Heart Study), J. Am. Coll. Cardiol., 2015, 66(15):1643-53.

7. AGATSTON A.S., JANOWITZ W.R., HILDNER F.J., ZUSMER N.R., VIAMONTE M. Jr., DETRANO R., Quantification of coronary artery calcium using ultrafast computed tomography, J. Am. Coll. Cardiol., 1990, 15(4):827-32.

8. HOU Z.H., LU B., GAO Y., JIANG S.L., WANG Y., LI W. et al., Prognostic value of coronary CT angiography and calcium score for major adverse cardiac events in outpatients, JACC Cardiovasc. Imaging, 2012, 5(10):990-9.

9. SHARMA A.M., Adipose tissue: a mediator of cardiovascular risk, Int. J. Obes. Relat. Metab. Disord., 2002, 26 Suppl 4:S5-7.

10. BACHAR G.N., DICKER D., KORNOWSKI R., ATAR E., Epicardial adipose tissue as a predictor of coronary artery disease in asymptomatic subjects, Am. J. Cardiol., 2012, 110(4):534-8. 
11. DJABERI R., SCHUIJF J.D., VAN WERKHOVEN J.M., NUCIFORA G., JUKEMA J.W., BAX J.J., Relation of epicardial adipose tissue to coronary atherosclerosis, Am. J. Cardiol., 2008, 102(12):1602-7.

12. LANG R.M., BADANO L.P., MOR-AVI V., AFILALO J., ARMSTRONG A., ERNANDE L. et al., Recommendations for cardiac chamber quantification by echocardiography in adults: an update from the American Society of Echocardiography and the European Association of Cardiovascular Imaging, Eur. Heart J. Cardiovasc. Imaging, 2015, 16(3):233-70.

13. MAHABADI A.A., MASSARO J.M., ROSITO G.A., LEVY D., MURABITO J.M., WOLF P.A. et al., Association of pericardial fat, intrathoracic fat, and visceral abdominal fat with cardiovascular disease burden: the Framingham Heart Study, Eur. Heart J., 2009, 30(7):850-6.

14. GORTER P.M., DE VOS A.M., VAN DER GRAAF Y., STELLA P.R., DOEVENDANS P.A., MEIJS M.F. et al., Relation of epicardial and pericoronary fat to coronary atherosclerosis and coronary artery calcium in patients undergoing coronary angiography, Am. J. Cardiol., 2008, 102(4):380-5.

15. YUSUF S., HAWKEN S., OUNPUU S., BAUTISTA L., FRANZOSI M.G., COMMERFORD P. et al., Obesity and the risk of myocardial infarction in 27,000 participants from 52 countries: a case-control study, Lancet, 2005, 366(9497):1640-9.

16. RIMM E.B., STAMPFER M.J., GIOVANNUCCI E., ASCHERIO A., SPIEGELMAN D., COLDITZ G.A. et al., Body size and fat distribution as predictors of coronary heart disease among middle-aged and older US men, Am. J. Epidemiol., 1995, 141(12):1117-27.

17. SMITH U., HAMMERSTEN J., BJORNTORP P., KRAL J.G., Regional differences and effect of weight reduction on human fat cell metabolism, Eur. J. Clin. Invest., 1979, 9(5):327-32.

18. BARANDIER C., MONTANI J.P., YANG Z., Mature adipocytes and perivascular adipose tissue stimulate vascular smooth muscle cell proliferation: effects of aging and obesity, Am. J. Physiol. Heart Circ. Physiol., 2005, 289(5):H1807-13.

19. DUBROVSKA G., VERLOHREN S., LUFT F.C., GOLLASCH M., Mechanisms of ADRF release from rat aortic adventitial adipose tissue, Am. J. Physiol. Heart Circ. Physiol., 2004, 286(3):H1107-13.

20. DING J., KRITCHEVSKY S.B., HARRIS T.B., BURKE G.L., DETRANO R.C., SZKLO M. et al., The association of pericardial fat with calcified coronary plaque, Obesity (Silver Spring), 2008, 16(8):1914-9.

21. IACOBELLIS G., PISTILLI D., GUCCIARDO M., LEONETTI F., MIRALDI F., BRANCACCIO G. et al., Adiponectin expression in human epicardial adipose tissue in vivo is lower in patients with coronary artery disease, Cytokine, 2005, 29(6):251-5.

22. DING J., KRITCHEVSKY S.B., HARRIS T.B., BURKE G.L., DETRANO R.C., SZKLO M. et al., The association of pericardial fat with calcified coronary plaque, Obesity, 2008, 16(8):1914-9.

23. NAPPI C., PONSIGLIONE A., ACAMPA W., GAUDIERI V., ZAMPELLA E., ASSANTE R. et al., Relationship between epicardial adipose tissue and coronary vascular function in patients with suspected coronary artery disease and normal myocardial perfusion imaging, Eur. Heart J. Cardiovasc. Imaging, 2019, 20(12):1379-87.

24. COMMANDEUR F., SLOMKA P.J., GOELLER M., CHEN X., CADET S., RAZIPOUR A. et al., Machine learning to predict the long-term risk of myocardial infarction and cardiac death based on clinical risk, coronary calcium, and epicardial adipose tissue: a prospective study, Cardiovasc. Res., 2019.

25. ASLANABADI N., SALEHI R., JAVADRASHID A., TARZAMNI M., KHODADAD B., ENAMZADEH E. et al., Epicardial and pericardial fat volume correlate with the severity of coronary artery stenosis, J. Cardiovasc. Thorac. Res., 2014, 6(4):235-9.

Received November $28^{\text {th }} 2019$ 